\title{
白金電極上でのアノード分極後に観測される 次亜塩素酸塩の還元反応
}

\author{
小寺 史浩 $^{\circledR 1}$, 梅 田 実 $^{2}$, 山田 明文 ${ }^{2}$
}

\section{Electroreduction of Hypochlorite after Anodic Polarization on Pt Electrode}

\author{
Fumihiro Kodera $^{1}$, Minoru UMEdA ${ }^{2}$ and Akifumi YAmadA ${ }^{2}$ \\ ${ }^{1}$ Environmental Science Research Niigata, Advanced Ttechnology Center, 333-1, Minamiyachi, Niigata-shi, \\ Niigata 953-0135 \\ ${ }^{2}$ Department of Chemistry, Faculty of Engineering, Nagaoka University of Technology, 1603-1, Kamitomioka, \\ Nagaoka-shi, Niigata 940-2188
}

(Received 22 April 2005, Accepted 28 June 2005)

\begin{abstract}
We developed a new analysis method of hypochlorite using a reduction wave observed at about $600 \mathrm{mV}$ vs. Ag/AgCl, after the potential sweep direction was switched from anodic to cathodic. The measurement was performed using mirror-polished pure platinum as a working disk electrode. For the reduction wave observed at a switching potential of $1200 \mathrm{mV} v \mathrm{~s}$. $\mathrm{Ag} / \mathrm{AgCl}$, the cathodic peak current and the concentration showed a good linear relationship at a concentration range of $0.2 \sim 6.0 \mathrm{mg} \mathrm{dm}^{-3}$. The relative standard deviation $(n=3)$ of the reduction wave gave a good result of $\mathrm{RSD}<0.02$. This electrode reaction was investigated by varing the $\mathrm{pH}$ value, the switching potential, and the sweep rate. As a result, it is considered that the cathodic current can be attributed to the reduction of $\mathrm{HClO}$, which is formed by shifting the $\mathrm{pH}$ to the acidic direction based on water electrolysis during anodic polarization.
\end{abstract}

Keywords : hypochlorite; anodic polarization; electroreduction; platinum.

\section{1 緒 言}

次西塩素酸塩は, 飲料水の消毒剂として広く使用されて おり ${ }^{1)}$, 最近では電解機能水の活性種としても注目されて いる ${ }^{2)}$. 一方で，過剩使用による環境污染が社会問題とな っている ${ }^{1)}$ ここのように生活に非常に身近な化学種のひと つであり，その濃度管理は重要な意味を持つが，既存の分 析法は試薬の安全性や操作の煩雑さなど一長一短があ $り^{3)}$ ，よりよい測定法の開発が必要である。このような背 景から, 近年, 無試薬, 小型化等, 様々な利点を持つ電気 化学測定法に関心が集まり開発が行われている ${ }^{4) \sim 7)}$. 著者 らも，これまでにアノード反応と電位掃引法を組み合わせ

\footnotetext{
${ }^{1}$ 新潟県環境衛生研究所先端技術センター: 953-0135 新潟県新 潟市南谷内 $333-1$

2 長岡技術科学大学工学部化学系: $940-2188$ 新潟県長岡市上富 岡町 1603-1
}

た新規測定法について報告を行った ${ }^{8)}$ ・しかしながら，こ のアノード反応を応用した方法では, 低濃度領域 $(<1$ $\left.\mathrm{mg} \mathrm{dm}{ }^{-3}\right)$ において十分な感度を得ることができなかった. この理由のひとつとして, 定量に用いたアノード反応は式 (1) による $\mathrm{ClO}^{-}$のラジカル種への電極反応 ${ }^{9)}$ であるが, 緩衝作用を持たない通常の水の $\mathrm{pH}$ 範囲（5〜9）におい ては, $\mathrm{HClO} と \mathrm{ClO}^{-}$が式 (2) のように共存しており ${ }^{10)}$, $\mathrm{ClO}^{-}$のみの検出が困難であることが考えられる。

$$
\begin{aligned}
& \mathrm{ClO}^{-} \longrightarrow \mathrm{ClO} \cdot+\mathrm{e}^{-} \\
& \mathrm{HClO} \rightleftarrows \mathrm{ClO}^{-}+\mathrm{H}^{+} \\
& \mathrm{K}=2.9 \times 10^{-8} \mathrm{~mol} \mathrm{l}^{-1} \text { at } 25^{\circ} \mathrm{C}^{11)}
\end{aligned}
$$

この問題の解決策として, 著者らは, アノードからカソ ード方向へ電位掃引を折り返すことにより生じる還元波に 着目した。この反応の詳細は明らかにされていないが，水 


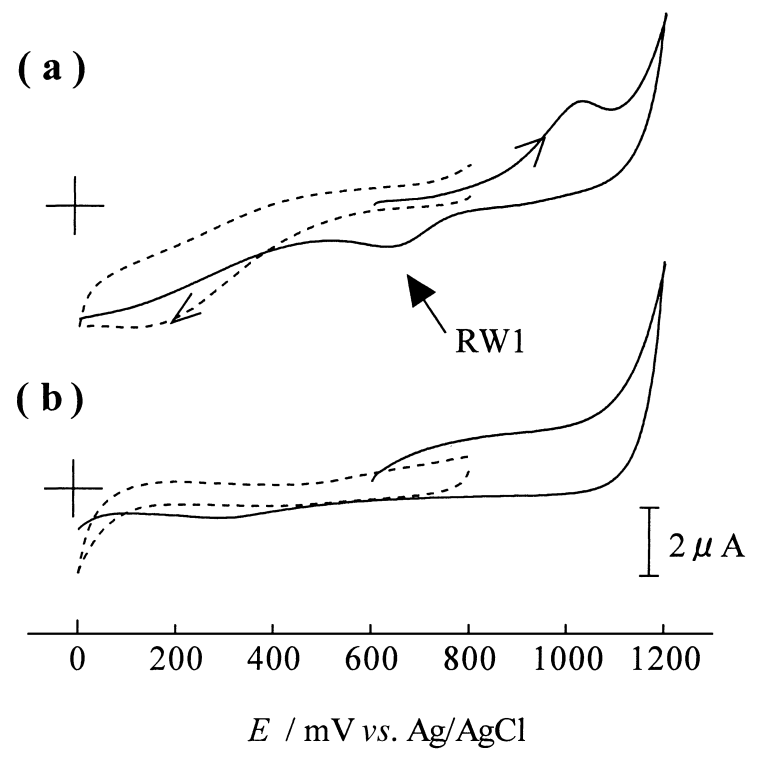

Fig. 1 Typical cyclic voltammograms of (a) $50 \mathrm{mg}$ $\mathrm{dm}^{-3} \mathrm{NaClO}$ in $0.1 \mathrm{M} \mathrm{NaClO}_{4}$, (b) blank $(0.1 \mathrm{M}$ $\left.\mathrm{NaClO}_{4}\right)$ on Pt disk electrode at a sweep rate of $50 \mathrm{mV}$ $\mathrm{s}^{-1}$ and $\mathrm{pH}=8.4$

Continuous line: Sweep from $E_{\text {rest }}$ to positive potential; Short dash line: Sweep from $E_{\text {rest }}$ to negative potential

の電気分解による $\mathrm{pH}$ 変化に関係していると考えられる. 本研究に打いては，この還元波の定量分析への応用及びそ のメカニズムについて検討を行ったので報告する.

\section{2 実験}

\section{$2 \cdot 1$ 試 薬}

測定に用いた標準溶液は，市販の有効塩素 8.5〜 13.5\% 次典塩素酸ナトリウム水溶液（ナカライテクス製）を，約 1000 と $100 \mathrm{mg} \mathrm{dm}{ }^{-3}$ に希釈することにより調整した。そ の標準溶液の精確な濃度はヨウ素滴定法により適宜標定し $た^{22}$. 支持電解質として過塩素酸ナトリウム (Merk 製) を用い ${ }^{13)}$, 溶液の $\mathrm{pH}$ の調整には過塩素酸（ナカライテク 又製）及び水酸化ナトリウム（和光純薬製）を用いた。 そ の他すべての試薬は市販特級を精製せずそのまま用いた。 すべての試薬の調整には，Milli-Q Labo（Millipore 製）に より精製した超純水を用いた。

\section{$2 \cdot 2$ 装 置}

電気化学測定には, コンピュータ制御の電気化学システ ム（BAS100B/W，ALS600A）を用い，作用極として白金 円盤電極 (1.6 mm diameter, BAS 製)，対極としてらせん 白金線，参照極として $\mathrm{Ag} / \mathrm{AgCl} （ 3 \mathrm{M} \mathrm{NaCl} ， \mathrm{BAS}$ 製）を用 いる温度調節機能付き 3 電極セルにて行った。試料溶液

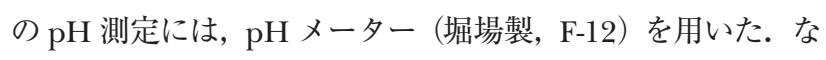
お，本文中の表記電位は， $\mathrm{Ag} / \mathrm{AgCl}$ に対する值を用いた。

\section{$2 \cdot 3$ 電極の前処理}

作用電極の表面は, 研磨紙 $(3 ， 2 ， 1 ， 0.5$ and $0.3 \mu \mathrm{m}$ of grain size，3M 製）にて鏡面研磨し，超純水にて注意深 く超音波洗浄を行った後, 電解質水溶液中にて有用な電位 範囲で電位掃引を繰り返すことによる前処理を行った．更 に, 再現性を向上させるため, 電極活性化処理を行っ た

\section{$2 \cdot 4$ 測定手順}

測定溶液の濃度は, 標準溶液をマイクロピペットを用い てセル中に滴下することにより調整した。調整した溶液の 測定は，レストポテンシャル $\left(E_{\text {rest }}\right)$ から正もしくは負方 向に電位掃引法にて行った。な㧍，遊離した塩素の経時変 化を防ぐため, 測定は溶液調整後直ちに行い, 特に断らな い限り溶液の除酸素は行わず，七ル温度 $25 \pm 11^{\circ} \mathrm{C}$ にて行 った.

\section{3 結果及び考察}

\section{$3 \cdot 1$ 次亜塩素酸塩の電極挙動}

Fig. 1 (a) に $50 \mathrm{mg} \mathrm{dm}^{-3} \mathrm{NaClO}$ のボルタモグラムを 示す（b)は，その空試験值である．実線は， $E_{\text {rest }}$ から正 方向へ電位掃引を開始し, $1200 \mathrm{mV}$ で負方向へ電位掃引 を折り返したボルタモグラム，破線は， $E_{\text {rest }}$ から負方向へ 電位掃引を開始し, $0 \mathrm{mV}$ で正方向へ電位掃引を折り返し たボルタモグラムである。（a）より，矢印で示した約 600 $\mathrm{mV}$ に折り返し掃引に伴う還元波（RW1）が観測された. この波は，破線の還元方向のみの掃引及び空試験における ボルタモグラムからは観測されない.したがって, 正方向 の掃引により生成した化学種の還元反応であると考えられ る.

Fig. 2 に, この $\mathrm{RW} 1$ のピーク電流と $\mathrm{NaClO}$ 濃度のプロ ットを示す．また，挿入図として $0.2 \sim 6.0 \mathrm{mg} \mathrm{dm}{ }^{-3}$ の濃 度範囲の拡大図を示す。な损，プロットにはバックグラウ ンドの電流を差し引いた值を用いた．Fig. 2 から，RW1 のピーク電流と濃度のプロットは $0.2 \sim 6.0 \mathrm{mg} \mathrm{dm}{ }^{-3}$ の低 濃度 $\left(-52.7 \mathrm{nA} / \mathrm{mg} \mathrm{dm}^{-3}\right)$ とそれ以上の濃度領域 ( $\left.\mathrm{nA} / \mathrm{mg} \mathrm{dm}^{-3}\right)$ において2つの傾きを示した.

この RW1の再現性について繰り返し測定を行った。各 濃度に打ける繰り返し試験 $(n=3)$ の結果を Table 1 に 示す. Table 1 から, 各濃度に扔ける相対標準偏差 (RSD) は $2 \%$ 未満とよい再現性を示した。

\section{$3 \cdot 2 \mathrm{pH}$ の影響}

水溶液中の遊離した塩素の形態は，式（２）に示したよ うに, $\mathrm{pH}$ に強く依存する。一般に $\mathrm{pH} 10$ 以上では次亜塩 素酸イオン $\left(\mathrm{ClO}^{-}\right), \mathrm{pH}$ 5 10 では次亜塩素酸 $(\mathrm{HClO})$ と次亜塩素酸イオン, $\mathrm{pH} 3 \sim 5$ では次車塩素酸, 更に $\mathrm{pH}$ 
3 以下では式 $(3)$ のように溶存塩素 $\left\{\mathrm{Cl}_{2}(\mathrm{aq})\right\}$ と次亜塩 素酸として存在し, 各化学種によって標準電極電位が異な $ろ^{3) 15)}$.

$$
\mathrm{Cl}_{2}(\mathrm{aq})+\mathrm{H}_{2} \mathrm{O} \rightleftarrows \mathrm{HClO}+\mathrm{Cl}^{-}+\mathrm{H}^{+}
$$

ここでは, 測定系の $\mathrm{pH}$ を過塩素酸 $\left(\mathrm{HClO}_{4}\right)$ と水酸化 ナトリウム $(\mathrm{NaOH})$ を用いて調整し，その影響について 検討を行った. Fig. 3 に $50 \mathrm{mg} \mathrm{dm}{ }^{-3} \mathrm{NaClO}$ のボルタモグ ラムにおける $\mathrm{pH}$ 依存性を示す。なお，各 $\mathrm{pH}$ における空 試験は, Fig. 1（b）のボルタモグラムにほぼ一致した.

Fig. 3 の実線に関して， $E_{\text {rest }}$ から正方向に電位掃引を行 うと, 塩基性領域において約 $1100 \mathrm{mV}$ に酸化波が観測さ れた. $1200 \mathrm{mV}$ で電位掃引を折り返し負方向に電位掃引 を進めると, $\mathrm{pH}$ 4 9 の範囲において, 約 $600 \mathrm{mV}$ に還元 波（RW1）が観測された. $\mathrm{pH}$ が 3 〜 6 の中性及び酸性領 域において，約 $800 \mathrm{mV}$ にもうひとつの還元波（RW2）が 観測される. 更に, 塩基性領域において, 約 $200 \mathrm{mV}$ に還 元波（RW3）が観測される. $\mathrm{pH}$ が 3 以下になるとこの RW3 は更に変化した。

一方で， $E_{\text {rest }}$ から負方向に電位掃引を行うと，塩基性領

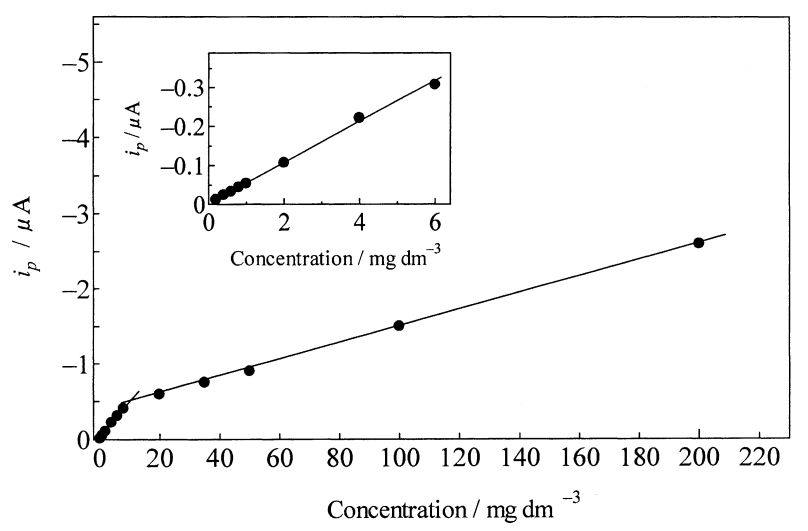

Fig. 2 Relationship between peak current and $\mathrm{NaClO}$ concentration

The plots of the inset were the concentration range of $0.2 \sim 6.0 \mathrm{mg} \mathrm{dm}^{-3}$.
域において約 $200 \mathrm{mV}$ に還元波（RW4）が観測される. $\mathrm{pH}$ が酸性に傾くとこの還元波は小さくなり，代わりに， 約 $600 \mathrm{mV}$ に還元波（RW5）が観測されるようになる. 更 に $\mathrm{pH}$ が酸性に傾くと，この RW2 の近傍，およそ 800 $\mathrm{mV}$ にもうひとつの還元波（RW6）が観測されるようにな る. 文献 ${ }^{15)}$ から溶存塩素の還元反応は, 次のように与えら れる。

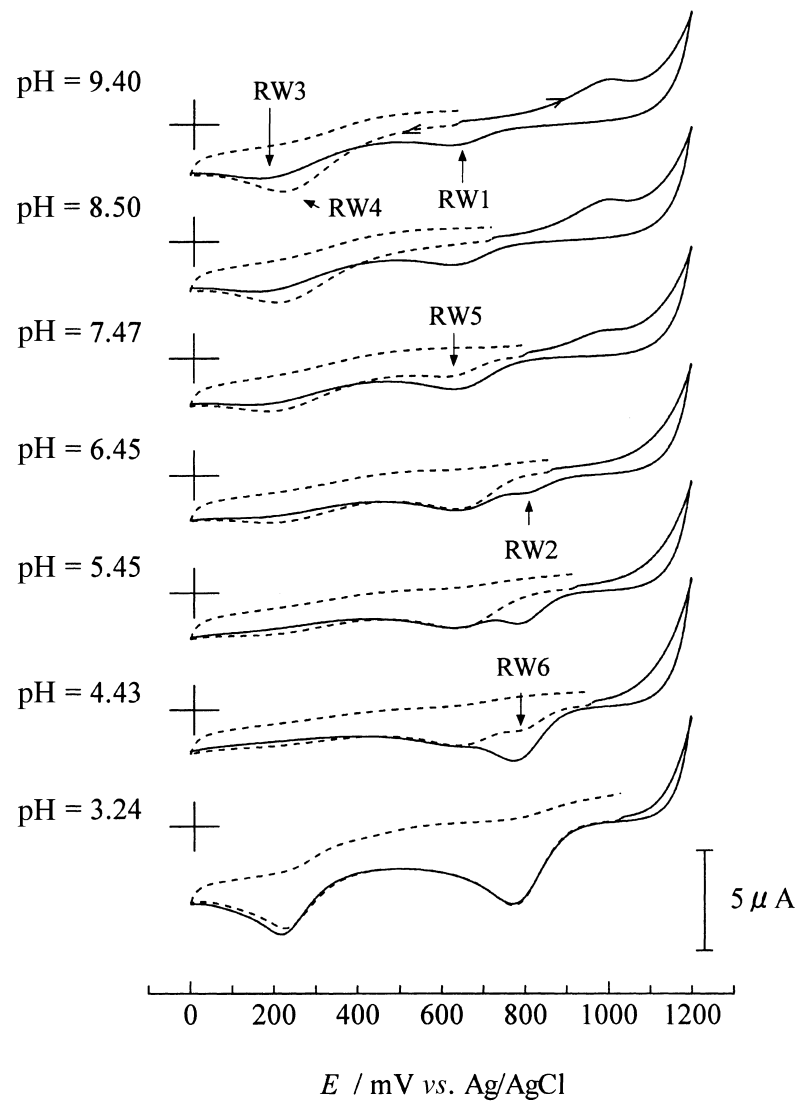

Fig. 3 Cyclic voltammograms as a function of $\mathrm{pH}$ for $50 \mathrm{mg} \mathrm{dm}{ }^{-3} \mathrm{NaClO}$ in $0.1 \mathrm{M} \mathrm{NaClO}_{4}$ at sweep rate 50 $\mathrm{mV} \mathrm{s}^{-1}$

Continuous line: Sweep from $E_{\text {rest }}$ to positive potential; Short dash line: Sweep from $E_{\text {rest }}$ to negative potential; The $\mathrm{pH}$ was adjusted with $\mathrm{HClO}$ and $\mathrm{NaOH}$.

Table 1 Repeatability test at different $\mathrm{NaClO}$ concentration

\begin{tabular}{|c|c|c|c|c|c|c|}
\hline \multirow{2}{*}{$\begin{array}{l}\text { Concentration/ } \\
\mathrm{mg} \mathrm{dm}^{-3}\end{array}$} & \multicolumn{5}{|c|}{$I_{\mathrm{p}} / \mu \mathrm{A}$} & \multirow{2}{*}{$\operatorname{RSD}^{\mathrm{b})}, \%$} \\
\hline & 1 & 2 & 3 & Mean & $\sigma^{\mathrm{a})}$ & \\
\hline 200 & 2.643 & 2.625 & 2.683 & 2.65 & 0.03 & 1.12 \\
\hline 50 & 0.964 & 0.972 & 0.942 & 0.959 & 0.02 & 1.62 \\
\hline 6 & 0.311 & 0.314 & 0.323 & 0.316 & 0.01 & 1.98 \\
\hline 0.6 & 0.033 & 0.034 & 0.033 & 0.034 & 0.00 & 1.89 \\
\hline
\end{tabular}

a) Standard deviation; b) Relative standard deviation 


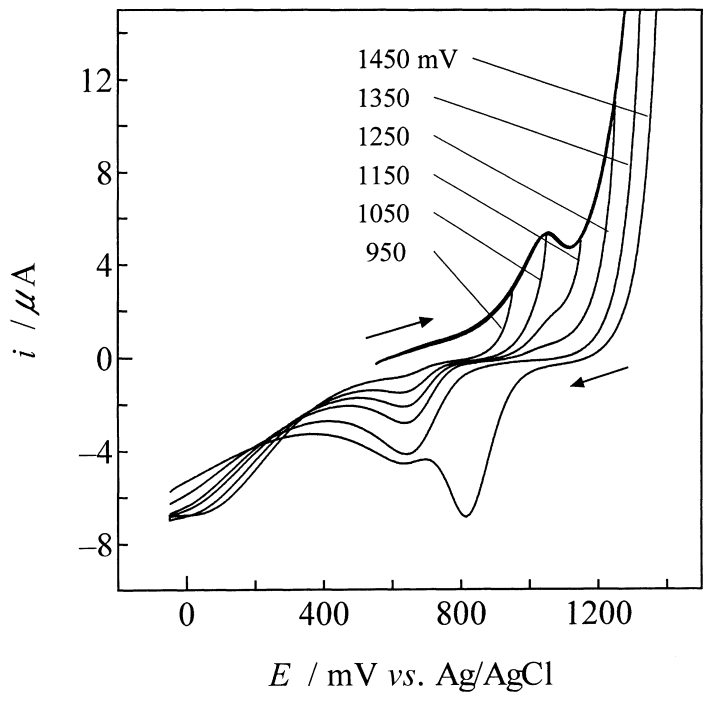

Fig. 4 Cyclic voltammograms as a function of switting potential for $100 \mathrm{mg} \mathrm{dm}^{-3} \mathrm{NaClO}$ in $0.1 \mathrm{M} \mathrm{NaClO}_{4}$ at sweep rate $50 \mathrm{mV} \mathrm{s}^{-1}$ and $\mathrm{pH}=8.70$

$$
\begin{aligned}
& \mathrm{ClO}^{-}+\mathrm{H}_{2} \mathrm{O}+2 \mathrm{e}^{-} \longrightarrow \mathrm{Cl}^{-}+2 \mathrm{OH}^{-} \\
& \mathrm{HClO}+\mathrm{H}^{+}+2 \mathrm{e}^{-} \longrightarrow \mathrm{Cl}^{-}+\mathrm{H}_{2} \mathrm{O} \\
& \mathrm{Cl}_{2}(\mathrm{aq})+2 \mathrm{e}^{-} \longrightarrow 2 \mathrm{Cl}^{-}
\end{aligned}
$$

反応式 $(2)$, (3) 及び測定系の $\mathrm{pH}$ から推測すると RW4 は式 (4) の次亜塩素酸イオン, RW5 は式 (5) の次 亜塩素酸, RW6 は式 (6) の溶存塩素の反応であると考え ることができる。また，酸性領域にて突如現れる還元波 は，溶存塩素の還元により生じた副生成物の反応であると 考えられる。

以上のことから，折り返し掃引に伴う還元波は，破線の 還元波と比較することにより，RW1 は次亜塩素酸， RW2 は溶存塩素, RW3 は次亜塩素酸イオンのそれぞれ還元反 応であると考えることができる．これらの RW1〜RW6の 還元波において， RW1 が，最も広い $\mathrm{pH}$ 範囲で観測され た。このことから，この RW1を応用することにより，緩 衝作用を持たない通常の水においても精確な測定が可能で あると期待される。次に，この反応の詳細について掃引電 位範囲及び掃引速度の観点から検討を行った。

\section{$3 \cdot 3$ 掃引電位範囲及び掃引速度の影響}

まず，掃引をアノードからカソードへ折り返す電位の影 響について検討を行った。Fig. 4 に折り返し電位を 950 , $1050 ， 1150 ， 1250 ， 1350 ， 1450 \mathrm{mV}$ と変化させた $100 \mathrm{mg}$ $\mathrm{dm}^{-3} \mathrm{NaClO}$ のボルタモグラムを示す。なお, 紙面の関係 上，内容に影響のないボルタモグラムの一部は削除した (電流值 $14 \mu \mathrm{A}$ 以上).

Fig. 4 から，約 $600 \mathrm{mV}$ に現れる RW1 は，折り返し電
位に強く依存し，電位が高くなるに従い増加した。一方 で，約 $200 \mathrm{mV}$ に現れる RW3 の電流值は，折り返し電位 が高くなるに従い減少した。これは，Fig. 3 における $\mathrm{pH}$ 6〜9のボルタモグラム変化にほぼ一致する。また， 1450 $\mathrm{mV}$ で電位掃引を折り返したところ，RW1 の近傍，約 800 $\mathrm{mV}$ にRW2 が観測された。これは，Fig. 3 における $\mathrm{pH} 4$ 〜6のボルタモグラム変化にほぼ一致する.以上のことか ら, RW1 の電極反応は, 次式 $(7)$ の水の電気分解 ${ }^{15)}$ によ り電極近傍の $\mathrm{pH}$ が酸性に傾き, 式 (2) の平衡が左に傾 くことにより生成した $\mathrm{HClO}$ の還元反応であると推測さ れる。

$$
\mathrm{H}_{2} \mathrm{O} \longrightarrow 1 / 2 \mathrm{O}_{2}+2 \mathrm{H}^{+}+2 \mathrm{e}^{-}
$$

また，折り返し電位がより高ければ，式 $(7$ ) の反応は より顕著に進むと考えられ，高い折り返し電位において観 測された還元波は，式（6）の溶存塩素の反応である可能 性が高い。

次に，掃引速度（v）を変化させその影響について検討 を行った. Fig. 5（a）に 10〜 $200 \mathrm{mV} \mathrm{s}^{-1}$ の範囲で掃引速 度を変化させた $100 \mathrm{mg} \mathrm{dm}{ }^{-3} \mathrm{NaClO}$ のボルタモグラムを 示す。（a）から，酸化波と同様の掃引速度依存性が RW1 においても観測された。その還元ピーク $\left(I_{\mathrm{pc}}\right) /$ 酸化ピー ク $\left(I_{\mathrm{pa}}\right)$ とvのプロットを（b）に示す.

（b）から，vを増大させるに従い $I_{\mathrm{pc}} / I_{\mathrm{pa}}$ は 1 に近づい ている. 後続化学反応を伴う電極反応では, 化学反応の逆 反応の速度を無視できる場合，vを増大させると $I_{\mathrm{pc}} / I_{\mathrm{pa}}$ は 1 に近づくことが知られている ${ }^{16)}$ 。このことは, 式 (1) において生成したラジカル種が式（８）の水素引き抜き反 応のようななんらかの形で, RW1 の反応に関与するひと つの可能性を示唆するものである.

$\mathrm{ClO} \cdot+\mathrm{H}_{2} \mathrm{O} \longrightarrow \mathrm{HClO}+\mathrm{OH} \cdot$

\section{$3 \cdot 4 \mathrm{ClO}_{2}{ }^{-}, \mathrm{ClO}_{3}{ }^{-}$の影響}

アノード全電極反応は, Foerster と Mullerにより次の ように報告されている ${ }^{17)}$.

$$
\begin{aligned}
& 6 \mathrm{ClO}^{-}+3 \mathrm{H}_{2} \mathrm{O} \longrightarrow \\
& 2 \mathrm{ClO}_{3}{ }^{-}+4 \mathrm{Cl}^{-}+6 \mathrm{H}^{+}+3 / 2 \mathrm{O}_{2}+6 \mathrm{e}^{-} \\
& 6 \mathrm{HClO}+3 \mathrm{H}_{2} \mathrm{O} \longrightarrow \\
& 2 \mathrm{ClO}_{3}{ }^{-}+4 \mathrm{Cl}^{-}+12 \mathrm{H}^{+}+3 / 2 \mathrm{O}_{2}+6 \mathrm{e}^{-}
\end{aligned}
$$

また, Tasaka と Tojo らにより, 素過程のプロセスにつ いて次のような報告がなされている ${ }^{18)}$. 

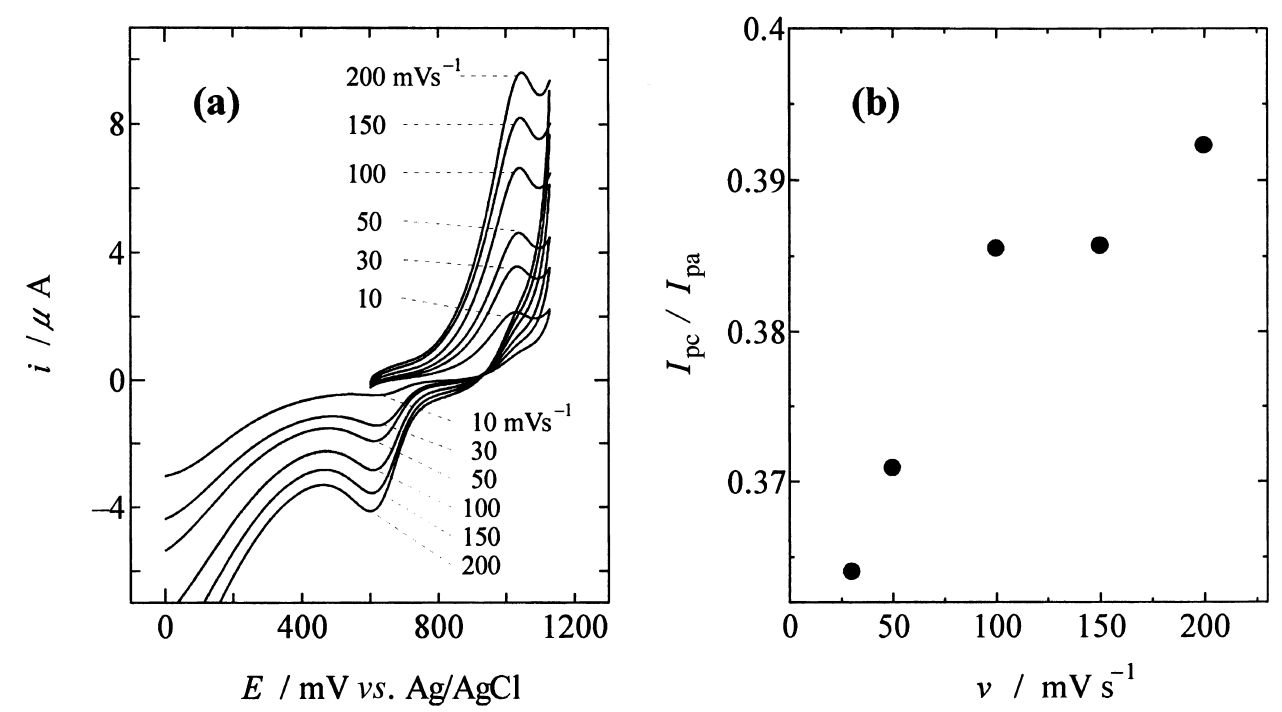

Fig. 5 Effect of sweep rate

(a) Cyclic voltammograms as a function of sweep rate for $100 \mathrm{mg} \mathrm{dm}^{-3} \mathrm{NaClO}$ at $\mathrm{pH}=$ 8.6 ; (b) $I_{\mathrm{pc}} / I_{\mathrm{pa}} v s . v$ plots

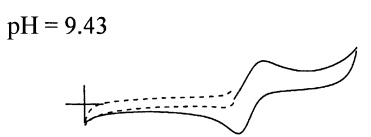

$\mathrm{pH}=9.67$
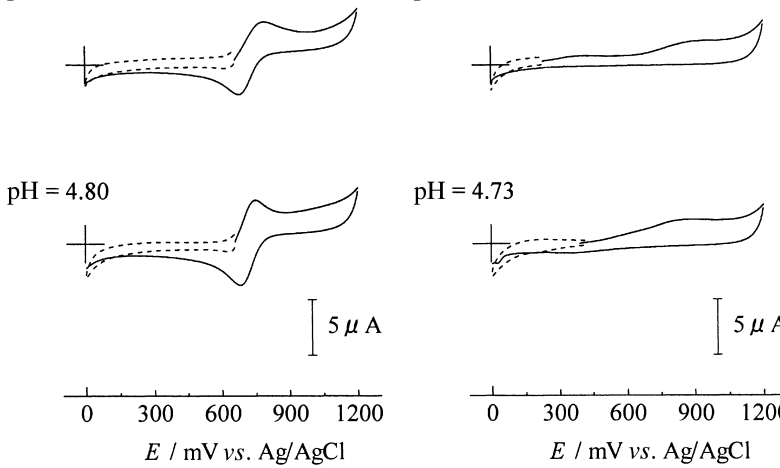

(a)

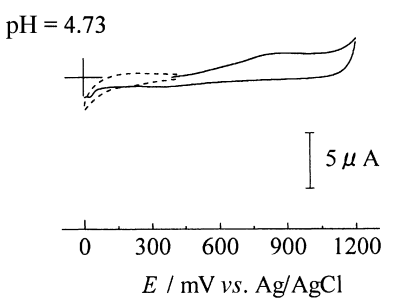

(b)

Fig. 6 Cyclic voltammograms of (a) $50 \mathrm{mg} \mathrm{dm}^{-3}$ $\mathrm{NaClO}_{2}$, (b) $50 \mathrm{mg} \mathrm{dm}{ }^{-3} \mathrm{NaClO}_{3}$ in $0.1 \mathrm{M} \mathrm{NaClO}_{4}$ as a function of $\mathrm{pH}$ at $\mathrm{Pt}$ disk electrode and sweep rate 50 $\mathrm{mV} \mathrm{s}^{-1}$

Continuous line: Sweep from $E_{\text {rest }}$ to positive potential; Short dash line: Sweep from $E_{\text {rest }}$ to negative potential

$$
\mathrm{ClO}^{-} \longrightarrow \mathrm{ClO}_{2}{ }^{-} \longrightarrow \mathrm{ClO}_{3}{ }^{-}
$$

このことから， $\mathrm{HClO}$ 以外にも $\mathrm{ClO}_{2}{ }^{-}$と $\mathrm{ClO}_{3}{ }^{-}$が $\mathrm{RW} 1$ の反応に関与している可能性が考えられる.ここでは, こ れらの化学種の影響について検討を行った.

Fig. 6 に $\mathrm{ClO}_{2}{ }^{-}$と $\mathrm{ClO}_{3}{ }^{-}$の $\mathrm{pH}$ 変化に対するボルタモグ ラムを示す。（a）は $\mathrm{ClO}_{2}{ }^{-}$，（b）は $\mathrm{ClO}_{3}{ }^{-}$のそれぞれボル 夕モグラムである。なお, 各空試験は, Fig. 1（b）にほ ぼ一致した。

（a）から，実線において $\mathrm{ClO}_{2}{ }^{-} / \mathrm{ClO}_{2}$ のレドックス反 応 ${ }^{19)}$ により生じた還元波が，上述した RW1 の電位近傍で 検出された。一方で破線において $\mathrm{ClO}_{2}{ }^{-}$の還元波は観測さ れなかった。このことは， $\mathrm{RW} 1$ の反応プロセスに $\mathrm{ClO}_{2}$ の 寄与する可能性を示唆する。しかしながら，通常の測定系 においては, $\mathrm{ClO}^{-}$から $\mathrm{ClO}_{2}{ }^{-}$，更には $\mathrm{ClO}_{2}$ へと進む反応 は考えにくく，たとえ $\mathrm{ClO}_{2}$ が生成したとしても，その存 在割合は無視できるほどわずかであると考えられる。（b） より, $\mathrm{ClO}_{3}{ }^{-}$に関する酸化及び還元波は観測されず，空試 験の挙動とほぼ同様であった．以上のことから RW1 の反 応における $\mathrm{ClO}_{2}{ }^{-}$と $\mathrm{ClO}_{3}{ }^{-}$の影響は無視できると考えられ る.

加えて, 溶液の $\mathrm{pH}$ を中性（6～7）に維持することで, 式(12)により $\mathrm{ClO}_{3}{ }^{-}$が生成されることが知られている ${ }^{20)}$. しかしながら，この反応が起こるためには，pHのみなら ず浴温度 $\left(60 \sim 110^{\circ} \mathrm{C}\right)$ が重要なファクターとなり，浴温 度が制御されている場合この影響は無視できる。

$$
2 \mathrm{HClO}+\mathrm{ClO}^{-} \longrightarrow \mathrm{ClO}_{3}^{-}+2 \mathrm{H}^{+}+2 \mathrm{Cl}^{-}
$$

\section{4 結 論}

アノードからカソード方向へ電位掃引を折り返すことに より約 $600 \mathrm{mV}$ に観測される還元波を応用した次亜塩素酸 塩の新規分析法について検討を行った。このリバース波の ピーク電流は， $0.2 \sim 6.0 \mathrm{mg} \mathrm{dm}{ }^{-3}$ の低濃度とそれ以上の 濃度領域において 2 つの傾きを持つ直線関係を示した。 また，その相対標準偏差 $(n=3)$ は， $2 \%$ 未満とよい再 
現性を示した．この電極反応について $\mathrm{pH}$, 折り返し電位, 掃引速度の観点から考察を行ったところ, 水の電解により $\mathrm{pH}$ が酸性に傾くことで生成した $\mathrm{HClO}$ の関与する反応で ある可能性が強く示唆された。

\section{文献}

1) IUPAC 編: “塩素白書”, (2000), (化学工業日報社).

2) 神崎 愷: ぶんせき (Bunseki), 2005, 131 .

3) J. Simper: Product Finish, 50, 4 (1997).

4) A. N. Tsaousis, C. O. Huber: Anal. Chim. Acta, 178, 319 (1985)

5) 池竹英人, 山田明文: 分析化学 (Bunseki Kagaku), 49, 977 (2000).

6) A. Okumura, A. Hirabayashi, Y. Sasaki, R. Miyake: Anal. Sci., 17, 1113 (2001).

7) J. Jin, Y. Suzuki, N. Ishikawa, T. Takeuchi : Anal. Sci., 20, 205 (2004).

8) F. Kodera, S. Kishioka, M. Umeda, A. Yamada: Jpn. J. Appl. Phys., 43, L913 (2004).

9) L. Czarnetzki, L. J. J. Janssen: Electrochimica Acta, 33, 561 (1988).
10) K. Noriyuki, T. Mitsuo: Electrochemistry, 73, 141 (2005).

11) J. C. Morris: J. Phys. Chem., 70, 3798 (1966).

12) APHA, AWWA, WCCF: "Standard Method for the Examination of Water and Wastewater", 18th ed., p. 4 (1992).

13) A. J. Bard, L. R. Faukner: "Electrochemical Methods, Fundamentals and Applications", 2nd ed. (2000), (John Wiley and Sons, New York).

14) W. R. LaCourse, D. C. Johnson: Anal. Chem., 65, 50 (1993).

15) 電気化学会編：“電気化学便覧”, 第 5 版, (2000), (丸 善).

16) R. S. Nicholson, I. Shain: Anal. Chem., 36, 706 (1964).

17) F. Foerster, E. Muller: Z. Elektrochem., 9, 171 (1903).

18) A. Tasaka, T. Tojo: J. Electrochem. Soc., 132, 1855 (1985).

19) N. Sinkaset, A. M. Nishimura, J. A. Pihl, W. C. Trogler: J. Phys. Chem. A, 103, 10461 (1999).

20) N. Ibl, D. Landolt: J. Electrochem. Soc., 115, 713 (1968).

要旨

アノード掃引からカソード掃引へ電位掃引方向を折り返すことにより約 $600 \mathrm{mV} v \mathrm{~s} . \mathrm{Ag} / \mathrm{AgCl}$ に観測され る還元波を応用した次亜塩素酸塩の新規分析法について検討を行った。測定は作用極として白金円盤電極を 用いた。折り返し電位を $1200 \mathrm{mV}$ vs. $\mathrm{Ag} / \mathrm{AgCl}$ とした場合，この還元波のピーク電流と濃度のプロットは $0.2 \sim 6.0 \mathrm{mg} \mathrm{dm}^{-3}$ の低濃度においてよい直線関係を示した。繰り返し測定による相対標準偏差は $2 \%$ 未满 $(n=3)$ とよい再現性を示した。この電極反応について $\mathrm{pH}$ ，折り返し電位，掃引速度の観点から考察を行 ったところ，水の電解により $\mathrm{pH}$ が酸性に傾くことで生成した $\mathrm{HClO}$ の関与する反応であることが示唆され た. 